\title{
Saliva of Rhipicephalus (Boophilus) microplus (Acari: Ixodidae) inhibits classical and alternative complement pathways
}

\author{
Naylene C. S. Silva', Vladimir F. Vale ${ }^{1,2}$, Paula F. Franco', Nelder F. Gontijo ${ }^{1,3}$, Jesus G. Valenzuela", \\ Marcos H. Pereira ${ }^{1,3}$, Mauricio R. V. Sant'Anna', Daniel S. Rodrigues ${ }^{5}$, Walter S. Lima', Blima Fux ${ }^{6}$ \\ and Ricardo N. Araujo ${ }^{1,3^{*}}$
}

\begin{abstract}
Background: Rhipicephalus (Boophilus) microplus is the main ectoparasite affecting livestock worldwide. For a successful parasitism, ticks need to evade several immune responses of their hosts, including the activation of the complement system. In spite of the importance of $R$. microplus, previous work only identified one salivary molecule that blocks the complement system. The current study describes complement inhibitory activities induced by R. microplus salivary components and mechanisms elicited by putative salivary proteins on both classical and alternative complement pathways.

Results: We found that $R$. microplus saliva from fully- and partially engorged females was able to inhibit both pathways. Saliva acts strongly at the initial steps of both complement activation pathways. In the classical pathway, the saliva blocked C4 cleavage, and hence, deposition of C4b on the activation surface, suggesting that the inhibition occurs at some point between $\mathrm{C} 1 \mathrm{q}$ and $\mathrm{C} 4$. In the alternative pathway, saliva acts by binding to initial components of the cascade (C3b and properdin) thereby preventing the C3 convertase formation and reducing C3b production and deposition as well as cleavage of factor B. Saliva has no effect on formation or decay of the C6 to C8 components of the membrane attack complex.

Conclusion: The saliva of $R$. microplus is able to inhibit the early steps of classical and alternative pathways of the complement system. Saliva acts by blocking C4 cleavage and deposition of C4b on the classical pathway activation surface and, in the alternative pathway, saliva bind to initial components of the cascade (C3b and properdin) thereby preventing the C3 convertase formation and the production and deposition of additional C3b.
\end{abstract}

Keywords: Rhipicephalus (Boophilus) microplus, Saliva, Complement inhibition, Classical pathway, Alternative pathway

\section{Background}

The cattle tick Rhipicephalus (Boophilus) microplus is the primary ectoparasite affecting livestock worldwide leading to considerable economic losses for cattle farming in tropical and subtropical areas of world [1-3]. This

\footnotetext{
* Correspondence: rnaraujo@icb.ufmg.br

'Departamento de Parasitologia, Laboratório de Fisiologia de Insetos Hematófagos, Universidade Federal de Minas Gerais, Belo Horizonte, MG, Brazil

${ }^{3}$ Instituto Nacional de Ciência e Tecnologia em Entomologia Molecular, Rio de Janeiro 21941-591, Brazil

Full list of author information is available at the end of the article
}

tick species also transmits pathogens, such as Babesia spp. and Anaplasma spp., that affect cattle farming [4].

While feeding, ticks, including $R$. microplus, secrete an arsenal of bioactive molecules that modulate the host immune system and haemostasis, which aids in the haematophagy and in the transmission of pathogens [5-7]. Indeed, ticks have salivary molecules that are capable of inhibiting the complement system [8-11]. Since the first description of complement inhibition by tick saliva in Ixodes dammini (syn. of I. scapularis, see [12]) [13], several tick salivary anti-complement molecules have been described [10, 14-16]. In spite of its importance, to date 
only one work has described the action of $R$. microplus saliva on the complement system [17].

The complement system is one the first lines of defence from vertebrate hosts and can be triggered by three pathways: the classical, the lectin and the alternative pathways [18]. The classical pathway is triggered when $\mathrm{C} 1 \mathrm{q}$ binds to the Fc region of antigen-bound IgM or IgG antibodies. Each C1rC1s dimer, composed of one $\mathrm{C} 1 \mathrm{r}$ and one $\mathrm{C} 1 \mathrm{~s}$ subunit, binds to one $\mathrm{C} 1 \mathrm{q}$ to form a $\mathrm{C} 1$ complex, which cleaves $\mathrm{C} 4$ and $\mathrm{C} 2$ to give $\mathrm{C} 4 \mathrm{~b}$ and $\mathrm{C} 2 \mathrm{a}$. These attach to the activation surface to form the C4bC2a enzyme (otherwise known as C3 convertase of the classical pathway). The $\mathrm{C} 3$ convertase cleaves multiple C3 molecules into C3b and C3a. C3b then associates with $\mathrm{C} 4 \mathrm{~b}$ from the $\mathrm{C} 3$ convertase to form the $\mathrm{C} 5$ convertase of the classical pathway (C4bC2aC3b) $[19,20]$.

The lectin pathway shares components with the classical pathway, but instead of antibodies and $\mathrm{C} 1$, the cascade is initiated by the binding of mannose-binding lectins (MBL) or ficolins to highly glycosylated pathogen-associated molecular patterns (PAMPs) present on the surface of a wide range of pathogens [21, 22].

Differently from the classical pathway, the alternative pathway is constantly activated and proceeds unless inactivated by plasma or membrane-bound regulatory molecules. The process is triggered when $\mathrm{C} 3 \mathrm{~b}$, which is always present in small amounts in the serum and extracellular fluids from C3 hydrolysis, covalently binds to activation surfaces and to $\mathrm{fB}$ that is subsequently cleaved by factor $\mathrm{D}$ to give the $\mathrm{C} 3$ convertases of the alternative pathway $(\mathrm{C} 3 \mathrm{bBb})$. These, in turn, produce additional C3b molecules thereby amplifying the cascade $[20,23]$. The C3 convertase is a labile enzyme stabilized by the aggregation of one properdin molecule that increases the half-life of the complex by at least 10-fold [24] and the ability of surface-bound $\mathrm{C} 3 \mathrm{~b}$ to interact with $\mathrm{fB}$ [25]. When a second C3b binds to the C3bBb complex, the alternative pathway $\mathrm{C} 5$ convertase is assembled (C3bBbC3b) [19, 20].

The C5 convertase formed from the three complement system activation pathways cleaves C5 into C5a and $\mathrm{C} 5 \mathrm{~b}$ thereby triggering the assembly of the membrane attack complex (MAC). Thus, C5b rapidly associates with $\mathrm{C} 6, \mathrm{C} 7$ and $\mathrm{C} 8$, and $\mathrm{C} 9$ molecules to form the C5b6789 or MAC, which is assembled on the surface of pathogens, thereby forming pores on the lipid bilayer of membranes $[18,26]$.

Complement pathways are highly regulated via many control proteins and intrinsic enzymatic activities that act mainly by: direct inhibition of serine proteases, decay and destruction of convertases and control of the MAC [19]. In addition to pores on lipid membranes, the complement is also an effector of humoral immunity and inflammation. Organism- or antigen-bound C3b aids in opsonisation and phagocytosis by effector cells in a process mediated by complement receptors [27, 28]. In addition, C3a and C5a are strong anaphylatoxins that induce damage by recruiting and stimulating granulocytes to release tissue-degrading enzymes, pro-inflammatory mediators and reactive oxygen species [18, 29].

Most of the described tick salivary proteins affecting the host's complement system come from tick species belonging to the genus Ixodes. In addition, most inhibit the complement alternative pathway by binding to properdin thus inducing the decay of the $\mathrm{C} 3$ convertase and also dissociating $\mathrm{Bb}$ from $\mathrm{C} 3 \mathrm{~b}[15,16]$. Besides inhibiting the alternative pathway, the Tick Salivary Lectin Pathway Inhibitor (TSLPI) of I. scapularis is also known to inhibit the lectin pathway by preventing the binding of MBL and ficolins to their ligands thus blocking the activation of the complement cascade [30]. Two other salivary proteins are known to inhibit the complement pathways: one (named AamAV422) described in Amblyomma americanum, which blocks the classical pathway [31], and another (named OmCI) in the argasid Ornithodoros moubata [32]. However, the inhibition mechanisms elicited by AamAV422 remain unexplored whereas it is known that OmCI binds to $\mathrm{C} 5$, thereby inhibiting both, the classical and alternative pathways [32]. Saliva of the neotropical tick Amblyomma cajennense was also shown to inhibit the classical pathway; however the inhibitor was not identified [33]. Recently, a new family of C5 inhibitors was identified with homolog sequences in the species Rhipicephalus appendiculatus, R. microplus, Dermacentor andersoni and Hyalomma marginatum [17]. Members of this family were shown to act similarly to OmCI, but binding to a different site at the C5 component.

Efforts towards finding the elusive salivary proteins of $R$. microplus affecting the host complement system and their mechanisms of action may be an important step to understand the relationship between parasite and host and to assist the identification of new vaccine targets against this ectoparasite. Indeed, conventional tick control is based on the expensive and labor-intensive treatment of animals with acaricides but their improper use has increased the incidence of acaricide-resistant ticks [34]. Here we confirmed the complement inhibitor activity in $R$. microplus saliva and investigated other mechanisms elicited by putative salivary proteins on the classical and alternative complement pathways.

\section{Methods}

\section{Obtaining ticks and saliva}

Rhipicephalus microplus ticks were collected from naturally infested adult crossbred cattle (Gir $\times$ Holstein) maintained in the Santa Rita Experimental Farm of the Agricultural Research Company of Minas Gerais 
(EPAMIG), located at Prudente de Morais, MG $\left(19^{\circ}\right.$ $\left.28^{\prime} 55^{\prime \prime S}, 44^{\circ} 09^{\prime} 18^{\prime \prime W}\right)$. Fully- (> $\left.4 \mathrm{~mm}\right)$ and partially $(<4$ $\mathrm{mm}$ ) engorged females were carefully detached from cattle skin, cleaned with distilled water and attached onto a surface with double-sided adhesive tapes. The saliva was obtained by injection of 3 to $6 \mu$ pilocarpine in $2 \% \mathrm{PBS}$ (136.8 mM NaCl; $2.7 \mathrm{mM} \mathrm{KCl,} 4.76 \mathrm{mM} \mathrm{Na}_{2} \mathrm{HPO}_{4}$ and $1.76 \mathrm{mM} \mathrm{KH} \mathrm{KH}_{4}$ ) into the ventro-lateral region of the body [14]. Saliva was collected for two hours directly from the mouthparts of the ticks using a pipette tip followed by centrifugation $(14,000 \times g$ for $5 \mathrm{~min})$ and the supernatant was stored at $-80{ }^{\circ} \mathrm{C}$ until use. Salivary total protein concentration was determined using bovine serum albumin as standard [35]. Briefly, three replicates of each aliquoted saliva were diluted $1: 10$ in $20 \mu \mathrm{l}$ distilled water and added to $200 \mu$ bradford solution $(0.1 \%$ Coomassie Brilliant Blue G-250, 5 \% ethanol and $8.5 \%$ phosforic acid). After $5 \mathrm{~min}$, the mixture was measured using a spectrophotometer (UV-1650PC Spectrophotometer, Shimadzu) at $595 \mathrm{~nm}$.

\section{Classical pathway haemolysis assays}

Classical pathway haemolytic assays were carried out using sheep erythrocytes according to Mendes-Souza et al. [36], modified from Whaley \& North [37]. Fresh sheep blood suspension $(500 \mu \mathrm{l})$, conserved in Alsever's solution at a ratio of $1: 1$, was washed three times with $5 \mathrm{ml}$ GHB-EDTA buffer $(0.1 \%$ gelatin, $5 \mathrm{mM}$ Hepes, $145 \mathrm{mM} \mathrm{NaCl}$ and $10 \mathrm{mM}$ EDTA, pH 7.4) followed by sensitisation of the erythrocytes with sheep antierythrocyte antibody $(1: 1,000)$. The erythrocytes were washed once with $5 \mathrm{ml}$ of GHB-EDTA buffer and twice with $5 \mathrm{ml} \mathrm{GHB}{ }^{2+}$ (GHB buffer supplemented with $0.15 \mathrm{mM}$ $\mathrm{CaCl}_{2}$ and $0.5 \mathrm{mM} \mathrm{MgCl}, \mathrm{pH} 7.4$ ) by centrifugation at $470 \times g$ for $5 \mathrm{~min}$ at $4{ }^{\circ} \mathrm{C}$. Erythrocyte concentration was adjusted to $2 \times 10^{8}$ cells $/ \mathrm{ml}$ before each experiment.

The haemolytic assays were conducted in a final volume of $125 \mu \mathrm{l}$ containing up to $25 \mu \mathrm{l}$ of tick saliva or saline $(15.4 \mathrm{mM} \mathrm{NaCl}$ in $100 \mathrm{ml})$ and $50 \mu \mathrm{l}$ of normal human serum (NHS) diluted in $\mathrm{GHB}^{2+}$ buffer at a ratio of $1: 60$. Aliquots of the erythrocyte solution $(50 \mu \mathrm{l})$ were added to the assays and the reaction was incubated at $37{ }^{\circ} \mathrm{C}$ for $30 \mathrm{~min}$. After incubation, the reaction was stopped by the addition of $500 \mu \mathrm{l}$ of ice-cold saline. Haemolysis was measured spectrophotometrically at $414 \mathrm{~nm}$. All assays were carried out in duplicate with at least three biological replicates. For each experiment, three different controls (without saliva and with pilocarpine) were used as follows: total haemolysis (saline was substituted by distilled water); positive control (haemolysis caused by serum without any sample); and negative control (without NHS where only spontaneous haemolysis is present). NHS aliquots (stored at $-80{ }^{\circ} \mathrm{C}$ ) were submitted to one freezing and thawing cycle and had their concentration adjusted in order to generate at least $90 \%$ of the total haemolysis. The results were expressed as percentage of haemolysis inhibition in relation to the positive control.

\section{Alternative pathway haemolysis assays}

For the alternative pathway, unsensitised rabbit blood was used as activating surface [36, 37]. Aliquots of fresh rabbit blood $(500 \mu \mathrm{l})$ conserved in Alsever's solution in a 1:1 ratio were washed three times with $5 \mathrm{ml} \mathrm{Mg-EGTA}$ solution (5 mM Hepes, $145 \mathrm{mM} \mathrm{NaCl}, 100$ mM EGTA, $7 \mathrm{mM} \mathrm{MgCl}_{2}, 0,1 \%$ gelatin, $\mathrm{pH}$ 7.4) by centrifugation at $470 \mathrm{~g}$ for $5 \mathrm{~min}$ at $4{ }^{\circ} \mathrm{C}$. EGTA chelates the divalent cation $\mathrm{Ca}^{2+}$, but not $\mathrm{Mg}^{2+}$, thereby inhibiting the activation of the classical pathway and leaving only the alternate pathway active. The concentration of erythrocytes was adjusted to $2 \times 10^{8}$ cells $/ \mathrm{ml}$ as above. The haemolytic assays were conducted using $50 \mu \mathrm{l}(1: 10)$ NHS diluted in Mg-EGTA buffer solution. The other procedures were similar to that used for the classical pathway described above.

\section{Enzyme-linked immunosorbent assays for the classical pathway}

The classical pathway assays were performed as described before [38]. Each well of a 96-well microplate $\left(\right.$ Costar $^{\oplus}$, code 9017) was sensitised with $2 \mu \mathrm{g}$ of purified human IgG in $50 \mu \mathrm{l}$ of carbonate/bicarbonate buffer ( $\left.15 \mathrm{mM} \mathrm{Na}_{2} \mathrm{CO}_{3}, 35 \mathrm{mM} \mathrm{NaHCO}, \mathrm{pH} 9.6\right)$ by overnight incubation in a humid chamber. IgG was purified from human serum by affinity chromatography using a Protein A-conjugated Sepharose bead column [39].

The sensitised wells were blocked with $200 \mu \mathrm{l}$ of blocking solution 1 (3\% skimmed milk powder in 10 $\mathrm{mM}$ Tris, $140 \mathrm{mM} \mathrm{NaCl}, \mathrm{pH}$ 7.4) followed by the addition of $200 \mu \mathrm{l}$ of blocking solution 2 (blocking solution 1 supplemented with $5 \mathrm{mM} \mathrm{CaCl}$ ), both incubated for 30 min at room temperature under agitation (150 rpm). After blocking, the saliva and human serum (1:100) in $100 \mu \mathrm{l}$ of sample buffer ( $5 \mathrm{mM}$ Hepes, $145 \mathrm{mM} \mathrm{NaCl}, 2 \mathrm{mM} \mathrm{CaCl}_{2}$, $1 \mathrm{mM} \mathrm{MgCl}_{2}, \mathrm{pH} \mathrm{7.4)}$ were incubated at $37^{\circ} \mathrm{C}$ for $30 \mathrm{~min}$ under agitation. Positive and negative controls (similarly to the haemolytic assays) were also included. The wells were washed three times with $200 \mu \mathrm{l}$ of washing solution (blocking solution 2 with $0.1 \%$ skimmed milk powder) at room temperature for 2 min under agitation.

The components deposited on the plate surface after the classical pathway activation were detected using $50 \mu \mathrm{l} /$ well of specific antibodies diluted in antibody buffer (10 mM Hepes, $140 \mathrm{mM} \mathrm{NaCl} \mathrm{pH} \mathrm{7.4)} \mathrm{incubated}$ for $30 \mathrm{~min}$ under agitation. The antibodies used are as follows: goat anti-human C1q (Sigma: C3900), goat antihuman C5b (Sigma: C3402) and goat anti-human C9 
(Sigma: A226) antibodies diluted at 1:2500; rabbit antihuman C3b (Sigma: C3402) and rabbit anti-human C4b (Sigma: C3402) diluted at 1:1000. These antibodies were diluted in antibody solution (10 mM Hepes, $140 \mathrm{mM}$ $\mathrm{NaCl} \mathrm{pH} \mathrm{7.4)} \mathrm{and} \mathrm{incubated} \mathrm{for} 30 \mathrm{~min}$ (150 rpm). Each well was then washed three times.

Antibodies were detected by the addition of $50 \mu \mathrm{l} /$ well of peroxidase-conjugated antibodies (rabbit anti-goat IgG (Sigma: A5420) diluted at a ratio of 1:2500 or mice anti-rabbit IgG (Sigma: A1949) diluted at 1:1500) in antibody solution. After washing, bound components were developed by addition of $200 \mu \mathrm{l}$ of peroxidase substrate solution $(1 \mathrm{mg} / \mathrm{ml}$ O-Phenylene-diamine (Sigma: P9029), $50 \mathrm{mM}$ sodium citrate, $0.075 \% \mathrm{H}_{2} \mathrm{O}_{2}$ (Synth: P22330) $\mathrm{pH} 5.5)$. Absorbance at $450 \mathrm{~nm}$ was measured in a microplate reader (Versamax, Molecular Devices) every $30 \mathrm{~s}$ for 10 (kinetic method) at $37^{\circ} \mathrm{C}$. The data generated were converted to percentage of deposition according to the following equation: [ $\left(\operatorname{Vmax}_{450 \mathrm{~nm}} \mathrm{mample}_{-} \mathrm{Vmax}_{450 \mathrm{~nm}}\right.$ sample solution $) /\left(\operatorname{Vmax}_{450 \mathrm{~nm}} \mathrm{NHS}\right.$ - Vmax.450nm sample solution) $] \times 100$.

Positive controls were considered as $100 \%$ deposition. The results were expressed as relative percentage inhibition by comparing the deposit levels in the experimental assays with the deposit levels obtained in the positive control experiments.

\section{Enzyme-linked immunosorbent assays for the alternative pathway}

Assays for the alternative pathway were performed with the addition of $100 \mu \mathrm{l} /$ well of $0.1 \%$ agarose solution and incubation at $37{ }^{\circ} \mathrm{C}$ for $24 \mathrm{~h}$ [38]. Saliva and NHS (7:100 ratio) were diluted in up to $100 \mu \mathrm{l}$ of HMEBN solution (5 mM Hepes, $7 \mathrm{mM} \mathrm{MgCl}_{2}, 10 \mathrm{mM}$ EGTA, $5 \mathrm{mg} / \mathrm{ml}$ BSA, $145 \mathrm{mM} \mathrm{NaCl}, \mathrm{pH}$ 7.4) were incubated for $30 \mathrm{~min}$ at $37{ }^{\circ} \mathrm{C}$ under agitation. After incubation, the wells were washed three times with $200 \mu \mathrm{l}$ of HMEBN for two min at room temperature and under agitation. The components deposited on the plate surface after the activation of the alternative pathway were detected using $50 \mu \mathrm{l} /$ well of the following specific antibodies: rabbit anti-human C3b, goat anti-human Bb (Comp Tech: A235), goat antihuman properdin (Comp Tech: A239), goat anti-human C5b or goat anti-human C9. Antibodies were diluted at $1: 1000$ in $\mathrm{HN}$ solution (10 mM Hepes, $145 \mathrm{mM} \mathrm{NaCl}$, $0.1 \%$ BSA, pH 7.4) and incubated for $30 \mathrm{~min}$ at room temperature under agitation. After incubation, the wells were washed as described above and $50 \mu \mathrm{l}$ of peroxidaseconjugated mice anti-rabbit IgG antibody or rabbit antigoat IgG. Conjugates were diluted at a 1:1500 ratio in $\mathrm{HN}$ solution and incubated for $30 \mathrm{~min}$ under agitation at room temperature. The wells were washed again and $200 \mu \mathrm{l}$ of peroxidase substrate solution were added. Absorbance at $450 \mathrm{~nm}$ was measured as above.

\section{Western blot analysis of complement factors cleavage}

The cleavage of $\mathrm{C} 4$ in human serum was assessed by Western blot using the supernatants from the classical pathway haemolytic assays [40]. Sample aliquots of $25 \mu \mathrm{l}$ (saline or $15 \mu \mathrm{g}$ salivary protein) were used to perform the classical pathway haemolytic assays as above. Reactions at 0 and $30 \mathrm{~min}$ were centrifuged (1,700 $g$ for $1 \mathrm{~min})$ and $25 \mu \mathrm{l}$ of the supernatant in reducing and denaturing buffer (10\% SDS and $5 \% \beta$-2-Mercaptoetanol) was applied on $10 \%$ SDS-PAGE electrophoretic analysis of the protein content [41]. The proteins in the gels were transferred to nitrocelulose membranes (Immunobilon-NC, Millipore) and incubated with goat anti-human C4 (Comp Tech: A205) diluted using a 1:2000 ratio in PBS/tween-20 for $2 \mathrm{~h}$ under agitation. The secondary antibody (rabbit anti-goat IgG peroxidase-conjugated) was diluted at a ratio of 1:4000 in PBS. Band identification was performed using the DAB Peroxidase Substrate Kit (Vector Laboratories, Burlingame, USA).

The C4 cleavage was also evaluated using purified components [40]. In $0.5 \mathrm{ml}$ tubes, $0.6 \mu \mathrm{g}$ of $\mathrm{C} 1 \mathrm{~s}$ was combined to $3 \mu \mathrm{g}$ of $\mathrm{C} 4$ and $15 \mu \mathrm{g}$ of salivary proteins in $30 \mu \mathrm{l}$ PBS total volume. Tubes containing $\mathrm{C} 4$ alone were used as negative control while tubes containing $\mathrm{C} 4$ and $\mathrm{C} 1 \mathrm{~s}$ without saliva were used as positive control. A tube containing $\mathrm{C} 4$ plus saliva was also used as control to evaluate possible $\mathrm{C} 4$ cleavage by salivary proteases. Samples were incubated for $2 \mathrm{~h}$ at $37^{\circ} \mathrm{C}$ and the enzymatic activity of $\mathrm{C} 1 \mathrm{~s}$ was measured by the presence of a $84 \mathrm{kDa} \alpha$ ' $\mathrm{C} 4$ fragment by Western blot as described above.

To analyse C3 cleavage, alternative pathway haemolytic assays were performed and analysed by Western blot as above except for the antibodies used: goat anti-human $\mathrm{C} 3$ (Comp Tech: A213) diluted using a 1:2000 ratio followed by addition of peroxidase-conjugated rabbit anti-goat IgG diluted at a ratio of 1:4000. For B cleavage analysis, the samples were applied on a native-PAGE and the antibodies used were goat anti-human factor B (Calbiochem : 401504) diluted 1:1000 and rabbit anti-goat IgG peroxidase-conjugated diluted at 1:2000 [15].

The cleavage of factor B was also evaluated using purified complement components [15]. The assay was carried out by combining $0.5 \mu \mathrm{g}$ factor $\mathrm{D}$ with $2 \mu \mathrm{g} \mathrm{fB}, 2 \mu \mathrm{g}$ $\mathrm{C} 3 \mathrm{~b}$ and $15 \mu \mathrm{g}$ of salivary proteins in $30 \mu \mathrm{l}$ PBS final volume supplemented with $5 \mathrm{mM} \mathrm{MgCl}_{2}$. Tubes containing only $\mathrm{fB}$ were used as negative control while tubes containing $\mathrm{fB}, \mathrm{C} 3 \mathrm{~b}$ and factor $\mathrm{D}$ without saliva were used as positive control. A control containing $\mathrm{fB}$ plus saliva evaluated the possible $\mathrm{fB}$ cleavage by salivary proteases. Samples were incubated for $30 \mathrm{~min}$ at $37{ }^{\circ} \mathrm{C}$. The enzymatic activity of the factor $\mathrm{D}$ on factor $\mathrm{B}$ was measured by Western blot visualising a $60 \mathrm{kDa} \mathrm{Bb}$ fragment, as described above. 


\section{Quantification of C3bBP formation by ELISA}

The C3 convertase precursor (C3bBP) was synthesised in vitro by combining C3b (Comp tech: A114), factor B (Comp tech: A135) and properdin (Comp: A139) (modified from [42]). The wells of 96-well microplates were coated with $50 \mu \mathrm{l} /$ well of C3b in PBS and incubated for $12 \mathrm{~h}$ at $4{ }^{\circ} \mathrm{C}$ in a humid chamber. The C3b-bound wells were then blocked with $200 \mu \mathrm{l}$ of PBS/Tween-20 solution containing $1 \% \mathrm{BSA}$ for $2 \mathrm{~h}$ at room temperature under agitation. Afterwards, the wells were washed three times with washing buffer $\left(8.1 \mathrm{mM} \mathrm{Na} \mathrm{HPO}_{4}, 1.8 \mathrm{mM}\right.$ $\mathrm{NaH}_{2} \mathrm{PO}_{4}, 25 \mathrm{mM} \mathrm{NaCl}, 10 \mathrm{mM} \mathrm{MgCl}, 0.05$ \% Tween20, $\mathrm{pH}$ 7.4) for 3 min under agitation. After the washings, up to $50 \mu \mathrm{l}$ saliva, factor $\mathrm{B}$ and properdin in binding buffer $\left(8.8 \mathrm{mM} \mathrm{Na}_{2} \mathrm{HPO}_{4}, 1.8 \mathrm{~mm} \mathrm{NaH}_{2} \mathrm{PO}_{4}, 0.05 \%\right.$ Tween-20, $75 \mathrm{mM} \mathrm{NaCl}, 10 \mathrm{mM} \mathrm{MgCl}_{2}, 1 \% \mathrm{BSA}$, $\mathrm{pH}$ 7.4) were added to the wells and incubated for $30 \mathrm{~min}$ at $37{ }^{\circ} \mathrm{C}$ under agitation followed by one washing cycle. An antibody mixture $(50 \mu \mathrm{l})$, containing either anti-fB or anti-properdin antibody in antibody binding buffer (8.8 $\mathrm{mM} \mathrm{Na}_{2} \mathrm{HPO}_{4}, 1.8 \mathrm{mM} \mathrm{NaH}_{2} \mathrm{PO}_{4}, 0.05 \%$ tween-20, $25 \mathrm{mM} \mathrm{NaCl}, 10 \mathrm{mM} \mathrm{MgCl}, 1 \% \mathrm{BSA}$ ) at $\mathrm{pH}$ 7.4, was incubated on the wells for $30 \mathrm{~min}$ at room temperature under agitation. This step was followed by three washes as described above. A solution (50 $\mu \mathrm{l} /$ well $)$ of rabbit anti-goat IgG peroxidase-conjugated at a ratio of 1:2000 in antibody solution was added to the wells and incubated for $30 \mathrm{~min}$ at room temperature under agitation. After the washes, components bound to the plate surface were developed with addition of $200 \mu \mathrm{l}$ of developing solution. Deposition levels (\%) were calculated using the following equation: $\left[\left(\mathrm{OD}_{450 \mathrm{~nm}}\right.\right.$ sample $-\mathrm{OD}_{450} \mathrm{~nm}$ only $\mathrm{C} 3 \mathrm{~b}$ in wells $) /\left(\mathrm{OD}_{450 \mathrm{~nm}}\right.$ sample without saliva $\mathrm{OD}_{450 \mathrm{~nm}}$ only C3b in wells) $] \times 100$ and used for statistical analysis.

\section{Binding of $R$. microplus saliva to components of the complement alternative pathway}

To analyse whether salivary molecules bind to components of the complement alternative pathway, 96-well microplates were coated with $10 \mu \mathrm{g}$ of $R$. microplus salivary protein or $1 \%$ BSA (negative controls) diluted in $50 \mu \mathrm{l}$ of carbonate/bicarbonate buffer by overnight incubation in a moist chamber at $4{ }^{\circ} \mathrm{C}$. The wells were then blocked with $200 \mu \mathrm{l}$ of blocking solution (PBS with $1 \%$ $\mathrm{BSA}$ ) and incubated for $1 \mathrm{~h}$ at room temperature under agitation. After blocking, $50 \mu \mathrm{l}$ of PBS containing $0.2 \mu \mathrm{g}$ of each component of the alternative pathway $(\mathrm{C} 3 \mathrm{~b}$, factor $\mathrm{B}$, properdin and factor $\mathrm{Bb}$ ) were incubated for $30 \mathrm{~min}$ at $37^{\circ} \mathrm{C}$ under agitation. Lastly, the wells were washed twice with $200 \mu \mathrm{l} \mathrm{PBS/tween-20}$ at room temperature for $2 \mathrm{~min}$ under agitation.

To detect plate-bound $\mathrm{C} 3 \mathrm{~b}$, properdin, factor $\mathrm{B}$ and $\mathrm{Bb}$, the wells were firstly incubated with primary antibodies (rabbit anti-human C3b, goat anti-human properdin, goat anti-human factor $\mathrm{B}$ and goat antihuman $\mathrm{Bb}$, respectively) diluted using a 1:5000 ratio, followed by the addition of the secondary antibodies (peroxidase-conjugated mice anti-rabbit IgG antibody and peroxidase-conjugated rabbit anti-goat IgG antibody at a dilution ratio of 1:3000). The components bound to the plates were exposed by the addition of $200 \mu \mathrm{l}$ of developing solution. The measurements and data analyses were performed as described above.

\section{ELISA for evaluation of the decay of factors of the complement alternative pathway}

ELISA assays were modified from a previously described protocol [16]. 96-well microplates were coated with $0.1 \%$ agarose at $37^{\circ} \mathrm{C}$ for $24 \mathrm{~h}$ and were then incubated with NHS in HMEBN solution at $37{ }^{\circ} \mathrm{C}$ for $30 \mathrm{~min}$ for convertases formation. Wells were washed with HMEBN solution and then incubated with $15 \mu \mathrm{g}$ of salivary protein in HMEBN for $30 \mathrm{~min}$ at $37^{\circ} \mathrm{C}$. After incubation, wells were again washed with $\mathrm{HMEBN}$ and the detection of microplate-bound components $(\mathrm{C} 3 \mathrm{~b}, \mathrm{Bb}$, Properdin, C5b or C9) was performed using primary specific antibodies (rabbit anti-human C3b, goat anti-human Bb, goat anti-human properdin, goat anti-human C5b or goat anti-human (9) followed by a secondary peroxidaseconjugated mice anti-rabbit IgG or rabbit anti-goat IgG, both diluted in HN solution and incubated for $30 \mathrm{~min}$ at room temperature. The development and percent deposition of factors on microplates were analysed as described above.

\section{Membrane attack complex (MAC) deposition assessment by haemolytic assay}

Classical pathway haemolytic assays were carried out as described in section 2.2 but using C6 (Comp tech: A323), C7 (Comp tech: A324) or C8 (Comp tech: A325) depleted serum diluted at 1:10 in $\mathrm{GHB}^{2+}$ [37]. Tubes were then centrifuged at $480 \mathrm{~g}$ for three min at $4{ }^{\circ} \mathrm{C}$ and erythrocytes were re-suspended in $300 \mu \mathrm{l}$ of GHB-EDTA solution and used in a second round of classical pathway haemolytic assay with NHS under the same conditions described on item 2.2.

On the first round, the complement system was activated and the components were deposited on the membrane of erythrocytes up to the point where the absence of the specific component under investigation halted the progress of the pathway, ultimately preventing the formation of the membrane attack complex (MAC). In the second round, the component present in the NHS (which was missing in the first round) resumes MAC formation (except if MAC inhibitors are present in the saliva) without a further activation of the classical pathway which is blocked by EDTA. 


\section{Statistical analysis}

Statistical analysis was performed using GraphPad Prism 5.0 software. All experiments were performed with at least three biological replicates in duplicate (haemolytic assays) or triplicate (deposition assays). The difference between groups was assessed using $t$-test (when comparing two groups) and ANOVA followed by Dunnett's or Bonferroni post-hoc tests (when comparing more than two groups). A $95 \%$ significance level $(P<0.05)$ was set as statistically significant.

\section{Results}

\section{Rhipicephalus microplus saliva inhibits both the classical} and the alternative pathway

Saliva from fully-engorged females was tested for inhibitory effects on the classical and alternative complement pathways using haemolytic assays. The results are summarized in Fig. 1a. Rhipicephalus microplus saliva was able to inhibit both of these pathways of the human complement system. This inhibition was dose-dependent: $5.09 \mu \mathrm{g}$ was the amount of salivary proteins needed to inhibit $50 \%$ of the classical pathway activity and $4.67 \mu \mathrm{g}$ was the amount of salivary proteins needed to inhibit $50 \%$ of the alternative pathway activity.

Fully- and partially engorged females produced different quantities and qualities of saliva when stimulated with pilocarpine. The average volumes and concentration of salivary proteins collected per tick were: $8.58 \mu \mathrm{l}$ at $0.76 \mu \mathrm{g} / \mu \mathrm{l}(n=55)$ and $1.52 \mu \mathrm{l}$ at $1.89 \mu \mathrm{g} / \mu \mathrm{l}(n=57)$ from fully- and partially engorged females, respectively. However, saliva from both engorgement phases produced a similar inhibitory effect on the classical ( $t$-test: $\left.t_{(4)}=1.27, P=0.27\right)$ and alternative pathways ( $t$-test: $t_{(4)}=0.19, P=0.43$ ) (Fig. 1b). As pilocarpine was used to stimulate tick salivation, pilocarpine control assays were carried out and showed no effect on either the classical or alternative pathways at 15, 30, 60 and $120 \mu \mathrm{g}$ (Additional file 1: Figure S1).

\section{Rhipicephalus microplus saliva inhibits the deposition of C4 by the classical pathway}

To determine which component of the classical complement pathway is affected by $R$. microplus saliva, we first adsorbed human IgG onto a 96-well microplate, then added human serum to allow the deposition of complement components in the activation surface and their recognition by specific antibodies. Saliva was unable to inhibit the deposition of $\mathrm{Clq}$ (repeated measures ANOVA: $\left.F_{(4,10)}=10.61, P=0.787\right)$, the first molecule of the classical complement activation pathway, on the microplate surface (Fig. 2a). However, it inhibited the deposition of C4b (repeated measures ANOVA: $F_{(4,10)}=4.77$, $P=0.029$, Fig. $2 \mathrm{~b}$ ) and all the subsequent factors such as C3b (repeated measure ANOVA: $F_{(4,10)}=6.86, P=0.011$, Fig. 2c), C5b (repeated measures ANOVA: $F_{(4,10)}=$ 10.43, $P=0.003$, Fig. 2d), and C9 (repeated measures ANOVA: $F_{(4,10)}=10.78, P=0.003$, Fig. $\left.2 \mathrm{e}\right)$.

\section{Rhipicephalus microplus saliva inhibits the cleavage of C4 by the classical pathway}

Next, we investigated the mechanism underlying the saliva-induced classical pathway inhibition. Since the inhibitory effect of saliva was first detected on the deposition of C4b, the supernatant of haemolytic assays activated by the classical pathway were evaluated by Western blot with anti-C4 polyclonal antibodies. In the control samples (containing serum, saline and erythrocytes incubated for $30 \mathrm{~min}$ ), the anti-C4 antibodies recognised the $\alpha(93 \mathrm{kDa}), \beta(75 \mathrm{kDa})$ and $\gamma(33 \mathrm{kDa})$ subunits of $\mathrm{C} 4$ as well as the $84 \mathrm{kDa} \alpha$ ' fragment, which is a product of $\mathrm{C} 4$ degradation. There was no $\alpha^{\prime}$ fragment in the treatment samples (containing serum, saliva
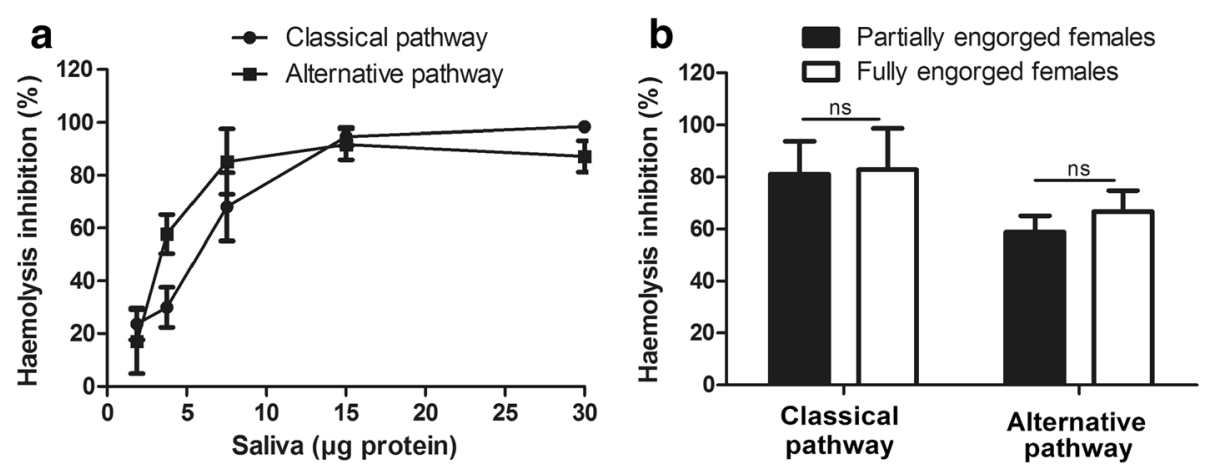

Fig. 1 Rhipicephalus microplus salivary inhibition of haemolysis by the classical and alternative pathways. A total volume of $125 \mu l$ was used for the haemolytic assay. Human serum was added to assess the effects of saliva on the process of haemolysis via the classical $(2.1 \mu \mathrm{l})$ and alternative $(12.5 \mu \mathrm{l})$ complement pathways, inducing at least $90 \%$ of haemolysis. In (a) different amounts of saliva were tested and in (b) $7.5 \mu \mathrm{g}$ of salivary proteins was used. Bars represent the arithmetic mean \pm standard deviation (SD) from three biological replicates. Abbreviation; ns, non-significant $(P>0.05)$ 


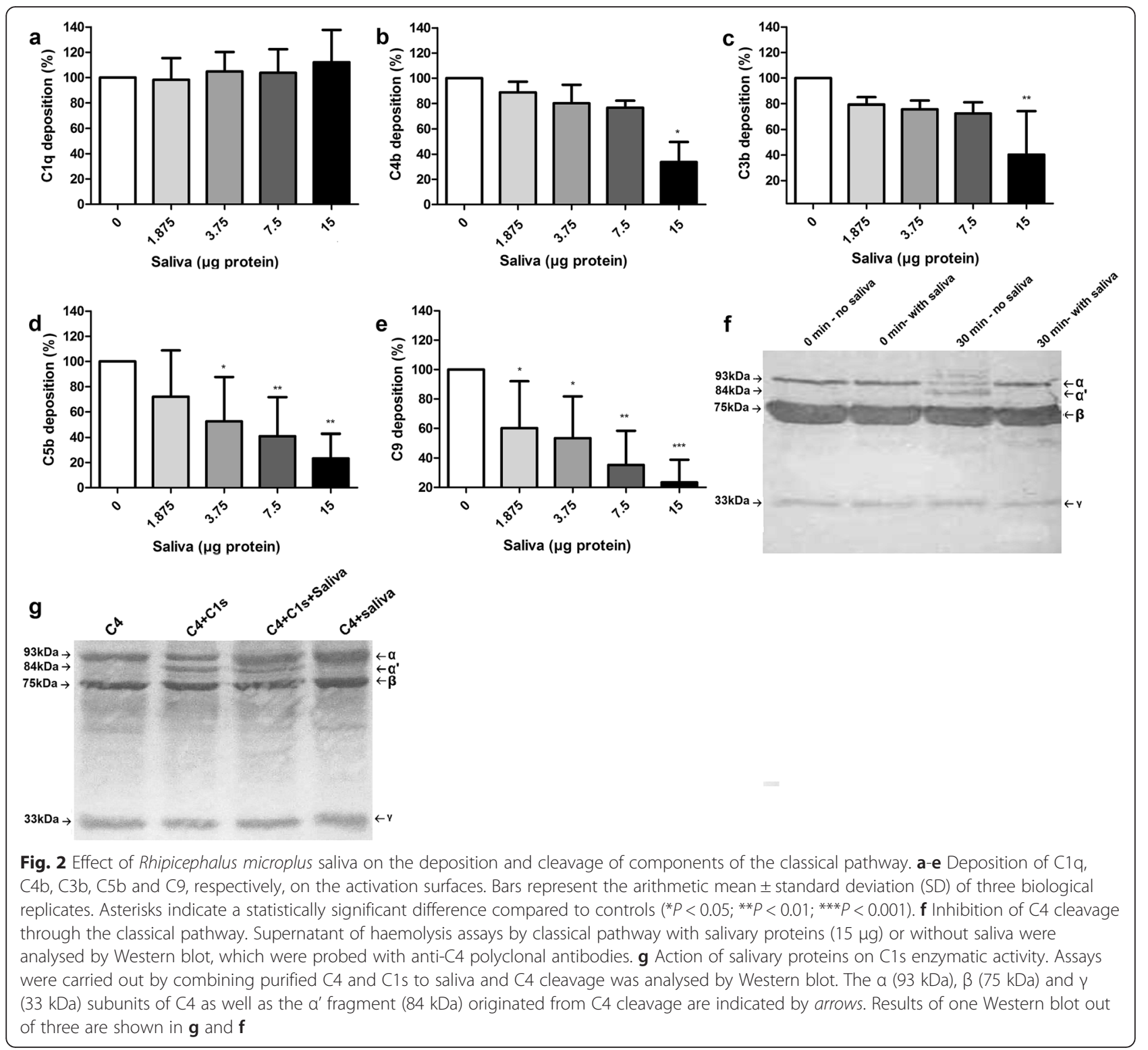

and RBCs incubated for $30 \mathrm{~min}$ ), indicating inhibition of C4 cleavage (Fig. 2f). As C4 is cleaved by $\mathrm{C} 1 \mathrm{~s}$ at the classical pathway, we then investigated the action of saliva on $\mathrm{C} 1 \mathrm{~s}$. However, the presence of salivary proteins did not affect the C1s-mediated cleavage of C4 (Fig. 2g).

\section{Rhipicephalus microplus saliva inhibits the deposition of $\mathrm{C} 3 \mathrm{~b}$ and $\mathrm{fB}$ by the alternative pathway}

To determine which component of the alternative complement cascade is affected by $R$. microplus saliva, we first adsorbed agarose onto the surface of a 96-well microplate, then added human serum to allow the deposition of complement components on the activation surface and their recognition by specific antibodies. Saliva significantly inhibited the deposition of C3b even when small amounts of salivary proteins were used (repeated measures ANOVA: $F_{(4,10)}=103.9, \quad P<0.001$, Fig. 3a). Consequently, all subsequent factors tested were also significantly inhibited such as $\mathrm{Bb}$ (repeated measures ANOVA: $F_{(4,10)}=29.26, P<0.001$, Fig. $\left.3 \mathrm{~b}\right)$ and $\mathrm{P}$ (repeated measures ANOVA: $F_{(4,10)}=32.12, P<0.001$, Fig. 3c), both of which form the $\mathrm{C} 3$ convertase and $\mathrm{C} 5 \mathrm{~b}$ (repeated measures ANOVA: $F_{(4,10)}=43.76, P<0.001$, Fig. 3d) and C9 (repeated measures ANOVA: $F_{(4,10)}=$ 51.07, $P<0.001$, Fig. 3 e), which are MAC components.

Rhipicephalus microplus saliva inhibits the cleavage of C3 and $\mathrm{fB}$ through the alternative pathway

The results above show that $R$. microplus saliva acts at the initial stages of activation of the alternative pathway. 


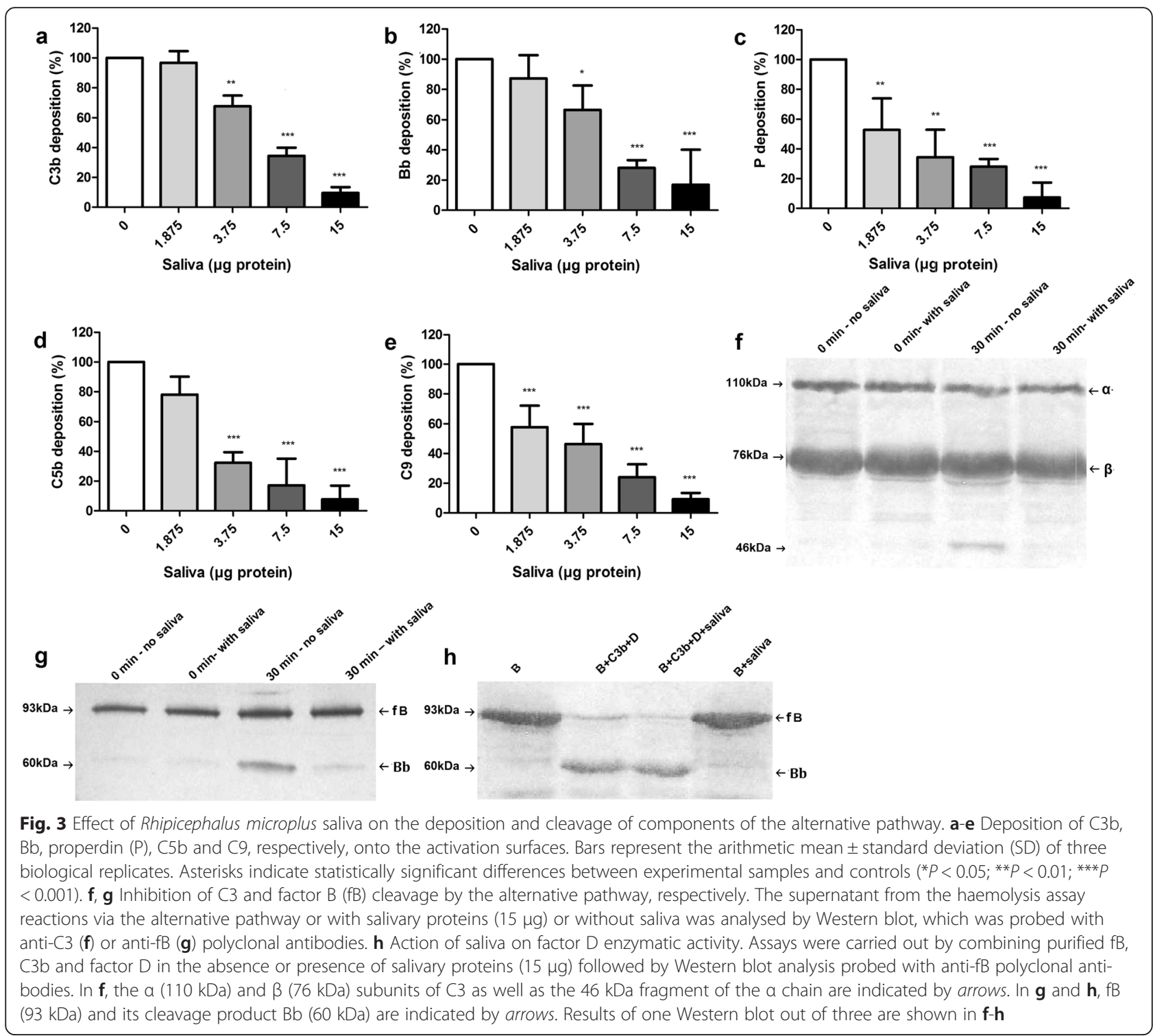

To further investigate how this inhibition occurs, we evaluated the activity of the saliva on the $\mathrm{C} 3$ and $\mathrm{fB}$ components. Alternative pathway haemolytic assays were performed and the supernatant of the reactions was evaluated by Western blot using anti-C3 and anti-fB polyclonal antibodies.

In the control samples (containing serum, saline and erythrocytes incubated for $30 \mathrm{~min}$ with the activation surface), the anti-C3 antibodies confirmed the presence of the $\alpha(110 \mathrm{kDa})$ and $\beta(76 \mathrm{kDa})$ subunits as well as a $46 \mathrm{kDa}$ band, which is the degradation product of the C3 $\alpha$ chain, indicating cleavage of C3. The $46 \mathrm{kDa}$ band was not seen in the treatment samples (containing serum, saliva and erythrocytes incubated for $30 \mathrm{~min}$ with the activation surface), indicating that saliva inhibits the production of C3b (Fig. 3f). The presence of saliva in the haemolytic assays also prevented the formation of $\mathrm{Bb}$ from $\mathrm{fB}$ (Fig. 3g), suggesting that the saliva inhibits the cleavage of $\mathrm{fB}$. The production of $\mathrm{Bb}$ in an assay where $\mathrm{AB}$ was combined to $\mathrm{C} 3 \mathrm{~b}$, factor $\mathrm{D}(\mathrm{D})$ and saliva indicates that saliva does not inhibit D-mediated cleavage of $\mathrm{fB}$ (Fig. 3h).

\section{Rhipicephalus microplus saliva inhibits the binding of $\mathrm{fB}$ to C3b through the alternative pathway}

To assemble the $\mathrm{C} 3$ convertase $(\mathrm{C} 3 \mathrm{bBb})$ of the alternative pathway, $\mathrm{fB}$ must bind to $\mathrm{C} 3 \mathrm{~b}$ and then be cleaved by factor D. Properdin stabilises the binding of C3b to $\mathrm{Bb}$. Therefore, we assessed the effects of $R$. microplus saliva on the formation of the C3b-fB-properdin complex. To this end, purified C3b was adsorbed onto the surface of a 96-well microplate, and then $\mathrm{fB}$ and 
properdin were added to assemble the C3bfBP complex (the precursor of $\mathrm{C} 3$ convertase) in the presence of $\mathrm{Mg}^{2+}$. Deposition of the components was analysed using anti-fB and anti-properdin polyclonal antibodies.

Saliva significantly reduced the binding of $\mathrm{fB}$ to $\mathrm{C} 3 \mathrm{~b}$ in a dose-dependent manner (repeated measures ANOVA: $F_{(4,10)}=23.26, P<0.001$, Fig. 4a), however it was only able to affect the binding of properdin to $\mathrm{C} 3 \mathrm{~b}$ when 15 $\mu \mathrm{g}$ of salivary proteins were added (repeated measures ANOVA: $F_{(4,10)}=3.92, P=0.048$, Fig. $\left.4 \mathrm{~b}\right)$. This shows that saliva inhibits the alternative pathway by interfering on the association of $\mathrm{C} 3 \mathrm{~b}$ and $\mathrm{fB}$, thereby preventing the formation of $\mathrm{C} 3$ convertase.

Rhipicephalus microplus saliva binds to $\mathrm{C} 3 \mathrm{~b}$ and properdin but not to factor $B$ to inhibit the alternative pathway

We coated 96-well microplates with saliva and incubated them with complement components $(\mathrm{C} 3 \mathrm{~b}$, factor $\mathrm{B}, \mathrm{Bb}$ and properdin) before adding specific antibodies to detect which components of the complement alternative pathway interact directly with saliva. As shown in Fig. 5, the molecules present in saliva only bound significantly to C3b (Bonferroni, $t=3.99, P<0.01$ ) and more strongly to properdin $(\mathrm{P})$ (Bonferroni, $t=7.94, P<0.001$ ).

\section{Rhipicephalus microplus saliva does not remove C3 convertase components deposited on alternative pathway activation surfaces}

As shown in Figs. 4 and 5, saliva prevents the formation of C3 convertase by inhibiting the deposition of components that are part of this enzyme and the association of $\mathrm{fB}$ and $\mathrm{C} 3 \mathrm{~b}$. Thus, we investigated whether saliva is also able to displace any of the $\mathrm{C} 3$ convertase components (C3b, fB and properdin) deposited via the alternative pathway. To this end, a 96-well microplate previously coated with agarose was incubated for $30 \mathrm{~min}$ with

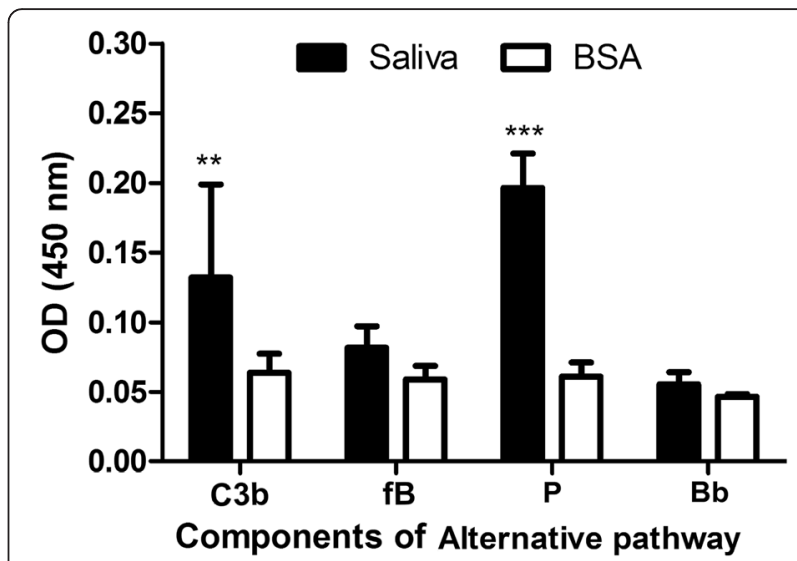

Fig. 5 Binding of components from the alternative complement pathway to the saliva of Rhipicephalus microplus. $\mathrm{fB}=$ factor $\mathrm{B}$; $P=$ properdin; $B S A=$ bovine serum albumin (control). Assays were performed by adsorbing saliva ( $10 \mu \mathrm{g}$ of salivary proteins) on a 96-well microplate followed by the addition of $\mathrm{C} 3 \mathrm{~b}$, fB, properdin and $\mathrm{Bb}$ purified components in the presence of $\mathrm{Mg}^{2+}$. The binding of the components was assessed using specific polyclonal antibodies. Bars represent the arithmetic mean \pm standard deviation (SD) of three biological replicates. Asterisks indicate significant difference from controls ( $\left.{ }^{*} P<0.01 ;{ }^{* *} P<0.001\right)$

human serum before saliva and anti-C3, anti-fB and anti-properdin polyclonal antibodies were added. We found that saliva is not able to remove $\mathrm{C} 3 \mathrm{~b}, \mathrm{fB}$ or properdin once these components of the alternative pathway have been deposited on the activation surface (Fig. 6).

Rhipicephalus microplus saliva does not inhibit deposition of C6-8 or remove pre-deposited components of the MAC The data presented above revealed that saliva acts at the initial activation steps of the complement cascade. As Jore et al. [17] have shown that saliva inhibits C5b
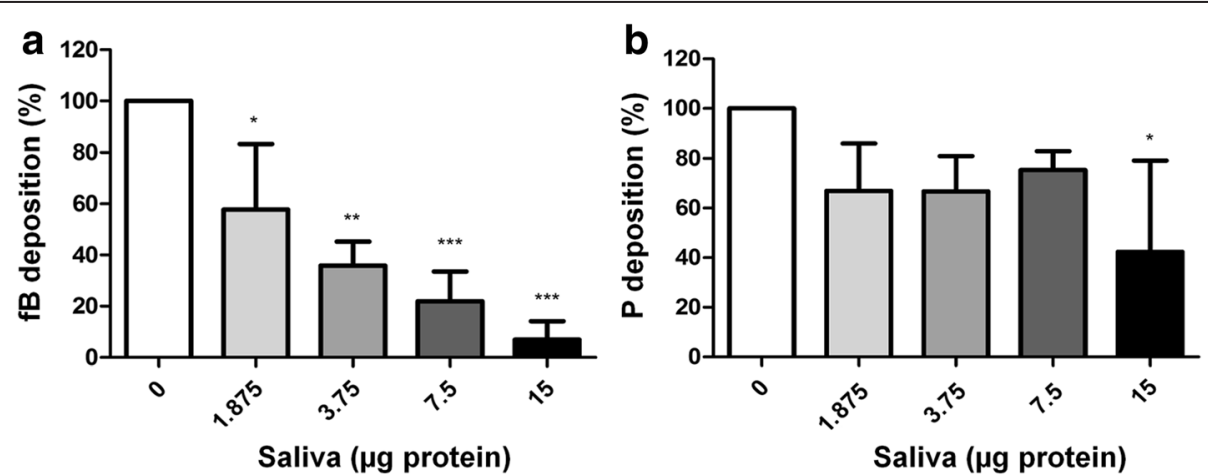

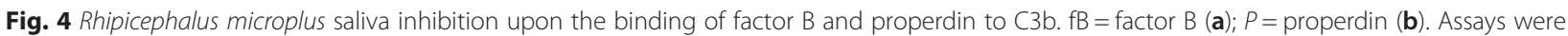
performed by adsorbing purified C3b on a 96-well microplate followed by the addition of purified fB and properdin in the presence of Mg ${ }^{2+}$. Different amounts of saliva were tested. The deposition of the components was assessed using anti-fB and anti-properdin polyclonal antibodies. Bars represent the arithmetic mean \pm standard deviation (SD) of three biological replicates. Asterisks indicate significant differences from controls $\left({ }^{*} P<0.05\right.$; ${ }^{* *} P<0.01$; $\left.{ }^{* *} P<0.001\right)$ 


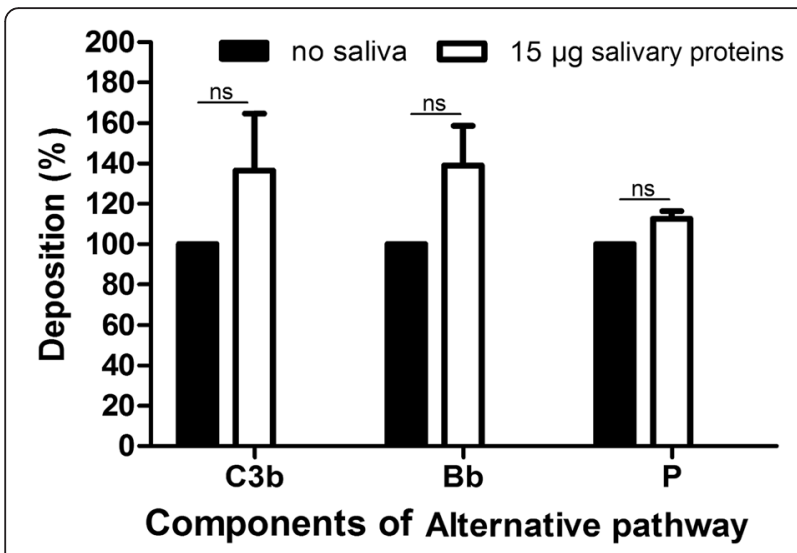

Fig. 6 Ability of Rhipicephalus microplus saliva to displace complement alternative pathway factors already deposited. $\mathrm{Bb}=$ factor $\mathrm{Bb} ; P=$ properdin. Human serum was added to $\mathrm{a}$ microplate pre-coated with agarose, leading to the formation of C 3 convertase. After $30 \mathrm{~min}$, R. microplus saliva was added and the presence of complement component deposits was evaluated using anti-C3, anti-factor B and anti-properdin polyclonal antibodies. Bars represent the arithmetic mean \pm standard deviation (SD) from three biological replicates. Statistically significant differences between samples with and without saliva were assessed using $t$-test (C $3 b t_{(2)}=1.31$, $P=0.32 ; B b t_{(2)}=1.99, P=0.18 ; P t_{(2)}=3.33, P=0.09$ ). Abbreviation: ns, non-significant $(P>0.05)$

deposition, we investigated whether saliva could also act directly on other components of the final stages of the complement pathway (mainly MAC components). To this end, we performed classical pathway haemolytic assays using sera depleted of one of the following MAC components: $\mathrm{C6}, \mathrm{C} 7$ or $\mathrm{C} 8$. These sera allowed us to investigate the activation of the complement cascade up to the deposition of the $\mathrm{C} 5 \mathrm{~b}, \mathrm{C} 6$ and $\mathrm{C} 7$ components, respectively. Normal human serum containing EDTA was then added to the assay to resume the complement cascade without new complement activation, as EDTA chelates $\mathrm{Ca}^{2+}$ and $\mathrm{Mg}^{2+}$ ions. Inhibition of haemolysis would indicate that saliva could be acting upon each MAC component. However, haemolysis did take place in the treatment samples, suggesting that saliva does not impair the deposition of $\mathrm{C} 6, \mathrm{C} 7$ and $\mathrm{C} 8$ on the activation surface (Fig. 7a).

Next, we evaluated whether saliva is also able to displace any of the MAC components (C5b and C9) already deposited on the activation surface via the alternative pathway. To this end, a 96-well microplate coated with agarose was incubated for $30 \mathrm{~min}$ with human serum before saliva and anti-C5b and anti-C9 polyclonal antibodies were added. Saliva is not able to remove neither C5b nor C9 after these components of the alternative pathway have already been deposited on the activation surface (Fig. 7b). Indeed, the presence of $\mathrm{C} 9$ on the activation surface indicates none of the previous components of MAC were removed.

\section{Discussion}

The huge economic and health impacts in the cattle industry caused by $R$. microplus has fostered research on how these ticks modulate host's immune system so that, ultimately, therapeutic strategies could be developed against these ectoparasites. It is well known that many tick species use bioactive molecules present in their saliva to inhibit the complement system [8-11]. However, in spite of their importance, only one $R$. microplus
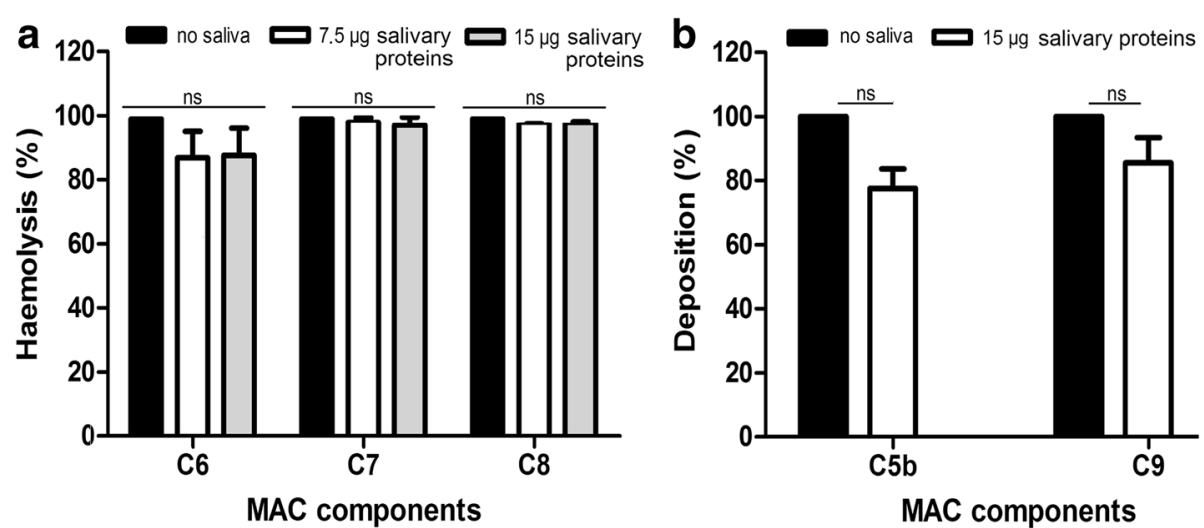

Fig. 7 Effect of Rhipicephalus microplus saliva on the membrane attack complex (MAC) components' deposition and removal. a Effect on MAC components' deposition: classical pathway-induced haemolysis was allowed to take place up to the point of C5, C6 or C7 deposition using C6-, C7- or C8-depleted serum, respectively. Normal human serum containing EDTA was then added to the assay to allow the haemolytic process to resume. Haemolysis levels were evaluated in each tube. $\mathbf{b}$ Effect on MAC components' removal: alternative complement pathway-induced MAC formation was allowed to occur in agarose-coated 96-well microplates. At this point, saliva was added and the presence of MAC components was evaluated using anti-C5b and anti-C9 polyclonal antibodies. Bars represent the arithmetic mean \pm standard deviation (SD) of three biological replicates. a Dunnet $\left(C 6 F_{(2,6)}=2.32, P=0.21 ; C 7 F_{(2,6)}=0.32, P=0.75 ; C 8 F_{(2,6)}=3.30, P=0.14\right)$ and $\mathbf{b} t$-test $\left(C 5 b t_{(2)}=3.68, P=0.07 ; C 9 t_{(2)}=1.82, P=0.21\right)$. Abbreviation: ns, non-significant $(P>0.05)$ 
salivary protein has been shown to affect the complement cascade [17]. The current study demonstrated that $R$. microplus saliva has other complement inhibitors able to block both the classical and the alternative pathways. Taken together, our results show that ticks have complement inhibitors acting on different points of the cascade, reinforcing the hypothesis that complement inhibition may be extremely important for tick's success.

The inhibition of both pathways makes the anticomplement activity present in $R$. microplus saliva different from that observed on ticks of the extensively studied genus Ixodes. Indeed, most of the Ixodes species with complement inhibition activity do so only through the alternative pathway, with both alternative and lectin pathways affected in only one tick species [10].

Saliva of partially and fully-engorged females induced similar levels of haemolysis inhibition when either the classical or alternative pathways were activated. In I. ricinus, inhibition of the alternative pathway has been present in the saliva at both engorgement stages although the levels of inhibition observed at the end of feeding were higher than those reported herein for $R$. microplus $[43,44]$.

The volume and concentration of the salivary proteins were remarkably different between the stages of engorgement. Fully-engorged females produced approximately six times more saliva than partially engorged ones. However, the protein concentration of the saliva produced by the partially engorged females was considerably higher compared to the saliva produced by fullyengorged females. This finding is in accordance to that reported in Tirloni et al. [45]. However, we found that the volume of saliva secreted at both stages of engorgement was approximately 10 times greater than that reported by these authors. These differences in volume of saliva production may be related to the time between the detachment of ticks from the host and pilocarpine stimulation or due to environmental conditions such as temperature and average relative humidity [46].

Here we showed that $R$. microplus saliva blocks the initial steps of the classical pathway. Indeed, saliva did not affect C1q deposition but prevented the deposition of $\mathrm{C} 4 \mathrm{~b}$, as confirmed by the data showing that the cleavage of $\mathrm{C} 4$ into $\mathrm{C} 4 \mathrm{~b}$ was blocked. Taken together, these results indicate that inhibition of the classical pathway occurs by preventing the cleavage of $\mathrm{C} 4$ by $\mathrm{C} 1 \mathrm{~s}$ and, hence, the formation of C4b. Saliva was not able to block $\mathrm{C} 1 \mathrm{~s}$ enzymatic activity. Therefore the possible inhibition mechanism could act preventing $\mathrm{C} 4$ binding to the assembled $\mathrm{C} 1$, displacing the serine proteases from the $\mathrm{C} 1$ complex or directly inhibiting $\mathrm{C} 1 \mathrm{r}$ activity. However, further research is required to investigate these hypotheses and improve our understanding on how $R$. microplus saliva inhibits the classical pathway.
To our knowledge, this is the first study showing inhibition of the early steps of the classical complement cascade by the saliva of an ixodid tick. Previous studies on $R$. microplus and other ixodid ticks showed inhibition of the final steps of the cascade [17]. Similar data are only available for other haematophagous arthropods, which also showed saliva-induced inhibition of the classical pathway at the initial stages. Indeed, Triatoma brasiliensis saliva prevented the deposition of $\mathrm{C} 4 \mathrm{~b}$ onto the activation surface [38] and molecules present in Lutzomyia longipalpis saliva prevented $\mathrm{C} 4$ cleavage and $\mathrm{C} 4 \mathrm{~b}$ deposition [47].

In haemathophagous animals, inhibition of the classical pathway has been shown to involve a mechanism mediated by calreticulin. In helminths, such as Necator americanus and Haemonchus contortus, calreticulin sequestrates $\mathrm{C} 1 \mathrm{q}$ and prevents its binding to antibodies, thereby blocking the classical pathway [48, 49]. Interestingly, calreticulin is also expressed in the saliva of several tick species [50-52] including $R$. microplus [53]. However, although calreticulin from $R$. microplus saliva has been shown to bind $\mathrm{C} 1 \mathrm{q}$, it did not inhibit the progression of the classical complement pathway [52].

The anticomplement activity described in the saliva of Ixodes ticks acts through the alternative pathway by inhibiting C3 convertase formation. This activity is based on the binding of the salivary active molecule to properdin and its removal from $\mathrm{C} 3$ convertase. In the absence of properdin, C3 convertase half-life is significantly shortened leading to a reduction in C3 convertase levels, thereby inhibiting the progression of the alternative pathway $[15,16]$.

The saliva of $R$. microplus also inhibited the haemolysis of rabbit erythrocytes mediated by the alternative pathway. We found that inhibition of the alternative pathway is related to the direct binding of $R$. microplus salivary protein(s) to $\mathrm{C} 3 \mathrm{~b}$ and properdin. The reduced deposition of $\mathrm{C} 3 \mathrm{~b}$ on wells covered with agarose was probably a consequence of the lack of formation of C3 convertase. Saliva does not block factor D activity, but it is plausible to suggest that binding of saliva to C3b and to properdin prevents the association of $\mathrm{fB}$ to $\mathrm{C} 3 \mathrm{~b}$ and, to a lesser extent, of properdin to $\mathrm{C} 3$ convertase thereby blocking the activation of the alternative pathway.

Rhipicephalus microplus saliva did not remove any of the components of C3 convertase, once it was assembled. This is a characteristic of the alternative pathway inhibitory activity found specifically in $R$. microplus saliva because the inhibition promoted by Ixodes anticomplement molecules directly removes pre-bound properdin and indirectly removes pre-bound $\mathrm{Bb}[15,16]$. These results suggest that $R$. microplus salivary anticomplement activity is attributed to a novel molecule with a different mechanism of action from that found in 
the saliva of the species belonging to the genus Ixodes. These data highlight the differences between the salivary activities of blood-sucking arthropods that, in the face of complexity, need to overcome similar anti-tick defence mechanisms of their hosts and ensure feeding success [54]. This hypothesis is supported by analyses of $R$. microplus databases that did not yield any significant hits to known complement inhibitors from Ixodes ticks (SALP20, IxACs, IRACs and ISACs).

The action of salivary inhibitors in the early stages of the complement cascade is highly efficient for the ticks: the saliva acts before the amplification of the complement signal which means that considerably fewer salivary molecules will be required to completely block the pathways. The inhibition of C3 convertase assemblage reduces the number of salivary molecules opsonised by $\mathrm{C} 3 \mathrm{~b}$ and prevents the presentation of these molecules to the host's immune system [38]. Moreover, without the production of $\mathrm{C} 3 \mathrm{~b}$ and $\mathrm{C} 5 \mathrm{~b}$, inflammatory mediators (such as C3a and C5a) cannot be produced at the bite site, and inflammation can be prevented. Absence of C3a may preclude homeostasis at the bite site since it also induces platelet activation and aggregation [55].

Rhipicephalus microplus saliva was previously shown to affect C5b deposition [17]. Here we demonstrated that it has no effect in $\mathrm{C} 6, \mathrm{C} 7$ or $\mathrm{C} 8$ deposition and in the removal of $\mathrm{C} 5 \mathrm{~b}$ or $\mathrm{C} 9$, deposited on the activation surface. Inhibition of $\mathrm{C} 5 \mathrm{~b}$ formation was also observed in argasid ticks for the OMCI, a salivary lipocalin of $O$. moubata [33]. Those molecules bind specifically to C5 thereby preventing its cleavage into $\mathrm{C} 5 \mathrm{~b}$ and $\mathrm{C} 5 \mathrm{a}$ by $\mathrm{C} 5$ convertases [17, 32]. Binding to C5 leads to an efficient complement inhibition mechanism because it blocks all activation pathways at once. However, the number of C5 molecules to be inhibited would be considerably high, since the cascade would have been already partially amplified with several inflammatory mediators produced, especially C3a.

\section{Conclusions}

Here we confirmed the presence of anti-complement activity in the saliva of $R$. microplus and showed the mechanisms by which it inhibits the early steps of classical and alternative pathways. Saliva acts strongly at the initial steps of both complement activation pathways by blocking the $\mathrm{C} 4$ cleavage and deposition of $\mathrm{C} 4 \mathrm{~b}$ on the alternative pathway activation surface. In the alternative pathway, saliva acts by binding to initial components of the cascade (C3b and properdin) thereby preventing the $\mathrm{C} 3$ convertase formation reducing $\mathrm{C} 3 \mathrm{~b}$ production and deposition. Rhipicephalus microplus saliva is not able to remove C3 convertase components deposited on alternative pathway activation surfaces and has no action on the formation or decay of the $\mathrm{C} 6, \mathrm{C} 7$ and $\mathrm{C} 8$ components of the MAC.
We suggest that this inhibitory activity is an important strategy performed by this tick species to modulate host's immune system. Further research is currently being carried out to identify bioactive agent(s) responsible for the complement inhibitory activity present in $R$. microplus saliva as these molecules may be potential therapeutic targets to reduce the burden of these ectoparasites on cattle farming.

\section{Additional file}

Additional file 1: Figure S1. Effect of pilocarpine on haemolysis by the classical and alternative pathways. Different concentrations of pilocarpine were tested using normal human serum via the classical (a) and alternative (b) complement pathways, inducing at least $90 \%$ of haemolysis. Bars represent the arithmetic mean \pm standard deviation (SD) of three biological replicates. (TIF $384 \mathrm{~kb}$ )

\section{Abbreviations}

BSA, bovine berum albumin; D, factor D; EDTA, ethylenediamine tetra-acetic acid; EGTA, ethylene glycol tetra-acetic acid; $\mathrm{AB}$, factor $\mathrm{B}$; IRAC, Ixodes ricinus anticomplement; ISAC, Ixodes scapularis anticomplement; IXACs, Ixodes anticomplement proteins; MAC, membrane attack complex; MBL, mannose binding lectin; NHS, normal human sera; OmCl, Ornithodorus moubata complement inhibitor; P, properdin; PAMPs, pathogen-associated molecular patterns; SALP20, Ixodes scapularis salivary protein 20; SDS-PAGE, sodium dodecyl sulfate polyacrylamide gel electrophoresis; TSLPI, tick salivary lectin pathway inhibitor

\section{Acknowledgements}

The authors would like to thank Mrs Marcia Gomes for her technical assistance. This manuscript was reviewed by a professional science editor and by a native English-speaking copy editor to improve readability.

\section{Funding}

The work was supported by Fundação de Amparo à Pesquisa do Estado de Minas Gerais (FAPEMIG), Conselho Nacional de Desenvolvimento Científico e Tecnológico (CNPq) and INCT- Entomologia Molecular.

\section{Availability of data and materials}

The datasets supporting the conclusions of this article are included within the article and Additional file 1.

\section{Authors' contributions}

NFG, MHP, JGV, MRVS and RNA participated in the design of the study and protocols. NCSS, VFV, PFF, DSR, BF and WSL conducted collection of material and lab experiments, processed the data and revised the manuscript. NCSS, VFV, NFG, JGV, MHP, MRVS, DSR, WSL, BF and RNA contributed to data analysis and interpretation, and revised the manuscript. NCSS and RNA wrote the manuscript. All authors read and approved the final manuscript.

\section{Competing interests}

The authors declare that they have no competing interests.

\section{Consent for publication}

Not applicable.

\section{Ethics approval and consent to participate} Not applicable.

\section{Author details}

${ }^{1}$ Departamento de Parasitologia, Laboratório de Fisiologia de Insetos Hematófagos, Universidade Federal de Minas Gerais, Belo Horizonte, MG, Brazil. 'Laboratório de Simulídeos e Oncocercose, Instituto Oswaldo Cruz, FIOCRUZ, Rio de Janeiro, RJ, Brazil. ${ }^{3}$ Instituto Nacional de Ciência e Tecnologia em Entomologia Molecular, Rio de Janeiro 21941-591, Brazil. ${ }^{4}$ Vector Molecular Biology Section, LMVR, National Institute of Allergy and 
Infectious Diseases, NIH, Rockville, MD, USA. ${ }^{5}$ Empresa de Pesquisa Agropecuária de Minas Gerais, Fazenda Experimental Santa Rita, Rodovia MG 424 km 64, Caixa Postal 295, Prudente de Morais 35701-970, MG, Brazil. ${ }^{6}$ Departamento de Patologia, Universidade Federal do Espírito Santo, Vitória, MG, Brazil.

Received: 3 March 2016 Accepted: 25 July 2016

Published online: 11 August 2016

\section{References}

1. Jonsson NN. The productivity effects of cattle tick (Boophilus microplus) infestation on cattle, with particular reference to Bos indicus cattle and their crosses. Vet Parasitol. 2006:137:1-10.

2. Rodrigues DC, Leite RC. Economic impact of Rhipicephalus (Boophilus) microplus: estimate of decreased milk production on a dairy farm. Arq Bras Med Vet Zoot. 2013;65:1569-72.

3. Grisi L, Leite RC, Martins JR, Barros AT, Andreotti R, Cancado PH, et al. Reassessment of the potential economic impact of cattle parasites in Brazil. Braz J Vet Parasitol. 2014;23:150-6.

4. Suarez CE, Noh S. Emerging perspectives in the research of bovine babesiosis and anaplasmosis. Vet Parasitol. 2011;180:109-25.

5. Ribeiro JM, Makoul GT, Levine J, Robinson DR, Spielman A. Antihemostatic, antiinflammatory, and immunosuppressive properties of the saliva of a tick, Ixodes dammini. J Exp Med. 1985:161:332-44.

6. Wikel SK. Host immunity to ticks. Annu Rev Entomol. 1996;41:1-22

7. Francischetti IM, Sa-Nunes A, Mans BJ, Santos IM, Ribeiro JM. The role of saliva in tick feeding. Front Biosci. 2009;14:2051-88.

8. Wikel SK, Allen JR. Acquired resistance to ticks. III. Cobra venom factor and the resistance response. Immunology. 1977;32:457-65.

9. Allen JR, Khalil HM, Wikel SK. Langerhans cells trap tick salivary gland antigens in tick-resistant guinea pigs. J Immunol. 1979;122:563-5.

10. Schroeder H, Skelly PJ, Zipfel PF, Losson B, Vanderplasschen A. Subversion of complement by hematophagous parasites. Dev Comp Immunol. 2009;33:5-13.

11. Papatheodorou V, Brossard M. C3 levels in the sera of rabbits infested and reinfested with Ixodes ricinus $\mathrm{L}$. and in midguts of fed ticks. Exp Appl Acarol. 1987:3:53-9.

12. Oliver Jr JH, Owsley MR, Hutcheson HJ, James AM, Chen C, Irby WS, et al. Conspecificity of the ticks Ixodes scapularis and I. dammini (Acari: Ixodidae). J Med Entomol. 1993;30:54-63.

13. Ribeiro JM. Ixodes dammini: salivary anti-complement activity. Exp Parasitol. 1987:64:347-53.

14. Valenzuela JG, Charlab R, Mather TN, Ribeiro JM. Purification, cloning, and expression of a novel salivary anticomplement protein from the tick, Ixodes scapularis. J Biol Chem. 2000;275:18717-23.

15. Couvreur B, Beaufays J, Charon C, Lahaye K, Gensale F, Denis V, et al. Variability and action mechanism of a family of anticomplement proteins in Ixodes ricinus. PLoS One. 2008:3:e1400.

16. Tyson KR, Elkins C, de Silva AM. A novel mechanism of complement inhibition unmasked by a tick salivary protein that binds to properdin. J Immunol. 2008;180:3964-8.

17. Jore MM, Johnson S, Sheppard D, Barber NM, Li YI, Nunn MA, et al. Structural basis for therapeutic inhibition of complement C5. Nat Struct Mol Biol. 2016;23:378-86

18. Dunkelberger JR, Song WC. Complement and its role in innate and adaptive immune responses. Cell Res. 2010;20:34-50.

19. Sim RB, Dodds AW. The complement system: an introduction. In: Dodds AW, Sim RB, editors. Complement: a practical approach. Oxford: University Press; 1997. p. 1-18.

20. Ricklin D, Hajishengallis G, Yang K, Lambris JD. Complement: a key system for immune surveillance and homeostasis. Nat Immunol. 2010:11:785-97.

21. Drickamer K. Ca2+-dependent carbohydrate-recognition domains in animal proteins. Curr Opin Struct Biol. 1993;3:393-400.

22. Ip WK, Takahashi K, Ezekowitz RA, Stuart LM. Mannose-binding lectin and innate immunity. Immunol Rev. 2009;230:9-21.

23. Ponnuraj K, Xu Y, Macon K, Moore D, Volanakis JE, Narayana SV. Structural analysis of engineered $\mathrm{Bb}$ fragment of complement factor $\mathrm{B}$ : insights into the activation mechanism of the alternative pathway C3-convertase. Mol Cell. 2004;14:17-28.

24. Fearon DT, Austen KF. Properdin: binding to C3b and stabilization of the C3b-dependent C3 convertase. J Exp Med. 1975;142:856-63.
25. DiScipio RG. The binding of human complement proteins $C 5$, factor $B$, beta $1 \mathrm{H}$ and properdin to complement fragment C3b on zymosan. Biochem J. 1981;199:485-96.

26. Taylor P, Botto M, Walport M. The complement system. Curr Biol. 1998:8:R259-61.

27. Colomb MG, Villiers CL, Villiers MB, Gabert FM, Santoro L, Rey-Millet CA. The role of antigen-bound C $3 \mathrm{~b}$ in antigen processing. Res Immunol. 1996;147:75-82.

28. Dempsey PW, Allison ME, Akkaraju S, Goodnow CC, Fearon DT. C3d of complement as a molecular adjuvant: bridging innate and acquired immunity. Science. 1996;271:348-50.

29. Kohl J. Anaphylatoxins and infectious and non-infectious inflammatory diseases. Mol Immunol. 2001:38:175-87.

30. Schuijt TJ, Coumou J, Narasimhan S, Dai J, Deponte K, Wouters D, et al. A tick mannose-binding lectin inhibitor interferes with the vertebrate complement cascade to enhance transmission of the lyme disease agent. Cell Host Microbe. 2011;10:136-46.

31. Mulenga A, Kim TK, Ibelli AM. Deorphanization and target validation of cross-tick species conserved novel Amblyomma americanum tick saliva protein. Int J Parasitol. 2013:43:439-51.

32. Nunn MA, Sharma A, Paesen GC, Adamson S, Lissina O, Willis AC, et al. Complement inhibitor of $\mathrm{C} 5$ activation from the soft tick Ornithodoros moubata. J Immunol. 2005:174:2084-91.

33. Franco PF, Silva NC, Fazito do Vale V, Abreu JF, Santos VC, Gontijo NF, et al. Inhibition of the classical pathway of the complement system by saliva of Amblyomma cajennense (Acari: Ixodidae). Exp Parasitol. 2016;164:91-6.

34. Abbas RZ, Zaman MA, Colwell DD, Gilleard J, lqbal Z. Acaricide resistance in cattle ticks and approaches to its management: The state of play. Vet Parasitol. 2014;203:6-20.

35. Bradford MM. A rapid and sensitive method for the quantitation of microgram quantities of protein utilizing the principle of protein-dye binding. Anal Biochem. 1976;72:248-54.

36. Mendes-Sousa AF, Nascimento AA, Queiroz DC, Vale VF, Fujiwara RT, Araujo $\mathrm{RN}$, et al. Different host complement systems and their interactions with saliva from Lutzomyia longipalpis (Diptera, Psychodidae) and Leishmania infantum promastigotes. PLoS One. 2013:8:e79787.

37. Whaley K, North J. Haemolytic assays for whole complement activity and individual components. In: Dodds AW, Sim RB, editors. Complement: A Practical Approach. Oxford: Oxford University Press Inc.; 1997. p. 19-47.

38. Barros VC, Assumpcao JG, Cadete AM, Santos VC, Cavalcante RR, Araujo $\mathrm{RN}$, et al. The role of salivary and intestinal complement system inhibitors in the midgut protection of triatomines and mosquitoes. PLoS One. 2009:4:e6047.

39. Catty D, Raykundalia C. Production and quality control of polyclonal antibodies. In: Catty D, editor. Antibodies a Practical approach. Washington: Press Oxford; 1989. p. 19-80

40. Avirutnan P, Fuchs A, Hauhart RE, Somnuke P, Youn S, Diamond MS, et al. Antagonism of the complement component C4 by flavivirus nonstructural protein NS1. J Exp Med. 2010;207:793-806.

41. Laemmli UK. Cleavage of structural proteins during the assembly of the head of bacteriophage T4. Nature. 1970;227:680-5.

42. Hourcade DE, Mitchell LM, Medof ME. Decay acceleration of the complement alternative pathway C3 convertase. Immunopharmacology. 1999:42:167-73.

43. Lawrie CH, Randolph SE, Nuttall PA. Ixodes ticks: serum species sensitivity of anticomplement activity. Exp Parasitol. 1999;93:207-14.

44. Daix V, Schroeder H, Praet N, Georgin JP, Chiappino I, Gillet L, et al. Ixodes ticks belonging to the Ixodes ricinus complex encode a family of anticomplement proteins. Insect Mol Biol. 2007;16:155-66.

45. Tirloni L, Reck J, Terra RM, Martins JR, Mulenga A, Sherman NE, et al. Proteomic analysis of cattle tick Rhipicephalus (Boophilus) microplus saliva: a comparison between partially and fully engorged females. PLoS One. 2014;9:e94831.

46. Bechara GH, Szabo MP, Machado RZ, Rocha UF. A technique for collecting saliva from the cattle-tick Boophilus microplus (Canestrini, 1887) using chemical stimulation. Environmental and temporal influences on secretion yield. Braz J Med Biol Res. 1988;21:479-84.

47. Ferreira VP, Fazito Vale V, Pangburn MK, Abdeladhim M, Mendes-Sousa AF, Coutinho-Abreu IV, et al. SALO, a novel classical pathway complement inhibitor from saliva of the sand fly Lutzomyia longipalpis. Sci Rep. 2016;6:19300. 
48. Kasper G, Brown A, Eberl M, Vallar L, Kieffer N, Berry C, et al. A calreticulin-like molecule from the human hookworm Necator americanus interacts with $\mathrm{Clq}$ and the cytoplasmic signalling domains of some integrins. Parasite Immunol. 2001;23:141-52.

49. Naresha S, Suryawanshi A, Agarwal M, Singh BP, Joshi P. Mapping the complement C1q binding site in Haemonchus contortus calreticulin. Mol Biochem Parasitol. 2009;166:42-6.

50. Xu G, Fang QQ, Keirans JE, Durden LA. Cloning and sequencing of putative calreticulin complementary DNAs from four hard tick species. J Parasitol. 2004;90:73-8.

51. Kaewhom P, Stich RW, Needham GR, Jittapalapong S. Molecular analysis of calreticulin expressed in salivary glands of Rhipicephalus (Boophilus) microplus indigenous to Thailand. Ann N Y Acad Sci. 2008;1149:53-7.

52. Kim TK, Ibelli AM, Mulenga A. Amblyomma americanum tick calreticulin binds $\mathrm{C} 1 \mathrm{q}$ but does not inhibit activation of the classical complement cascade. Ticks Tick Borne Dis. 2015;6:91-101.

53. Ferreira CA, Da Silva VI, da Silva SS, Haag KL, Valenzuela JG, Masuda A. Cloning and partial characterization of a Boophilus microplus (Acari: Ixodidae) calreticulin. Exp Parasitol. 2002;101:25-34.

54. Ribeiro JM, Francischetti IM. Role of arthropod saliva in blood feeding: sialome and post-sialome perspectives. Annu Rev Entomol. 2003;48:73-88.

55. Markiewski MM, Nilsson B, Ekdahl KN, Mollnes TE, Lambris JD. Complement and coagulation: strangers or partners in crime? Trends Immunol. 2007;28:184-92

\section{Submit your next manuscript to BioMed Central} and we will help you at every step:

- We accept pre-submission inquiries

- Our selector tool helps you to find the most relevant journal

- We provide round the clock customer support

- Convenient online submission

- Thorough peer review

- Inclusion in PubMed and all major indexing services

- Maximum visibility for your research

Submit your manuscript at www.biomedcentral.com/submit 